\title{
Concentrator and Space Applications of High-Efficiency Solar Cells- Recent Developments
}

S.R. Kurtz and D.J. Friedman

National Renewable Energy Laboratory

Presented at the National Center for

Photovoltaics Program Review Meeting

Denver, Colorado

September 8-11, 1998

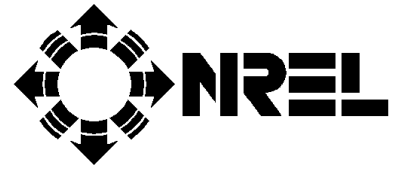

National Renewable Energy Laboratory 1617 Cole Boulevard Golden, Colorado 80401-3393

A national laboratory of the U.S. Department of Energy Managed by Midwest Research Institute for the U.S. Department of Energy under contract No. DE-AC36-83CH10093

Work performed under task number PV802601

October 1998 


\begin{abstract}
NOTICE
This report was prepared as an account of work sponsored by an agency of the United States government. Neither the United States government nor any agency thereof, nor any of their employees, makes any warranty, express or implied, or assumes any legal liability or responsibility for the accuracy, completeness, or usefulness of any information, apparatus, product, or process disclosed, or represents that its use would not infringe privately owned rights. Reference herein to any specific commercial product, process, or service by trade name, trademark, manufacturer, or otherwise does not necessarily constitute or imply its endorsement, recommendation, or favoring by the United States government or any agency thereof. The views and opinions of authors expressed herein do not necessarily state or reflect those of the United States government or any agency thereof.
\end{abstract}

Available to DOE and DOE contractors from:

Office of Scientific and Technical Information (OSTI)

P.O. Box 62

Oak Ridge, TN 37831

Prices available by calling 423-576-8401

Available to the public from:

National Technical Information Service (NTIS)

U.S. Department of Commerce

5285 Port Royal Road

Springfield, VA 22161

703-605-6000 or 800-553-6847

or

DOE Information Bridge

http://www.doe.gov/bridge/home.html 


\title{
Concentrator and Space Applications of High- Efficiency Solar Cells - Recent Developments
}

\author{
Sarah R. Kurtz and D. J. Friedman \\ National Renewable Energy Laboratory (NREL), 1617 Cole Blvd., Golden, CO 80401
}

\begin{abstract}
GaInP/GaAs cells invented and developed at NREL have achieved world-record efficiencies. We estimate that their production for space applications has grown to $>\$ 100$ million/yr. Approximately $300 \mathrm{MW} / \mathrm{yr}$ of $1000 \mathrm{X}$ terrestrial concentrator cells could be fabricated with the existing manufacturing capacity at a cost of about $21 \phi / \mathrm{Wp}$. A resurgence of interest in terrestrial PV concentrators, together with the strength of the III-V space-solar-cell industry, indicate that III-V cells are also attractive for terrestrial applications.
\end{abstract}

\section{INTRODUCTION}

The two-junction (cascade) $\mathrm{Ga}_{0.5} \mathrm{In}_{0.5} \mathrm{P} / \mathrm{GaAs}$ cell was invented in November 1984 at the National Renewable Energy Laboratory (NREL) (1) (see Fig. 1). Over the next few years, the growth and basic properties of $\mathrm{Ga}_{0.5} \operatorname{In}_{0.5} \mathrm{P}$ (hereafter, GaInP) were studied. As the purity of the source materials was improved and the device optimized, the efficiencies climbed: $4 \%$ in 1985 (2), 10\% in 1987 (3), 21.8\% in 1988 (4), and $27.3 \%$ in 1990 (5). When the two-junction efficiencies passed the efficiency of singlejunction GaAs, the cascade cell became attractive for space applications. The cascade cells provide a higher efficiency, lower temperature coefficient, improved radiation resistance, and reduced series-resistance losses, and they were recognized with an R\&D100 Award in 1991.

In 1994, world-record efficiencies were reported, $29.5 \%, 25.7 \%$, and $30.2 \%$ under AM1.5 global, AM0, and AM1.5 direct (150-200X), respectively $(6,7)$. Although the cascade cell requires carefully controlled growth of more than a dozen layers, NREL's work was quickly duplicated. Japan Energy Corporation, Spectrolab, and Applied Solar Energy Corporation (ASEC, currently TECSTAR) all reported cells with respectable efficiencies in 1994 (8-10). By 1996, ASEC reported manufacturing experience with the cascade cells (11), and Spectrolab reported growth of triple-junction cells (12).

In the two years since the last U.S. PV Review meeting, the GaInP/GaAs cell has been received very enthusiastically by the space PV community. The manufacturing and usage experience that accompanies the large space-PV production volumes is going a long way toward providing the terrestrial concentrator industry with a source of highefficiency, low-cost concentrator cells. Although it has not yet achieved a significant production level, the concentrator industry is progressing by installing new systems, developing new products, and working to establish standards for qualification testing. This paper describes recent advances in both the III-V and concentrator industries and discusses why these imply that III-V cells are attractive for terrestrial applications. 


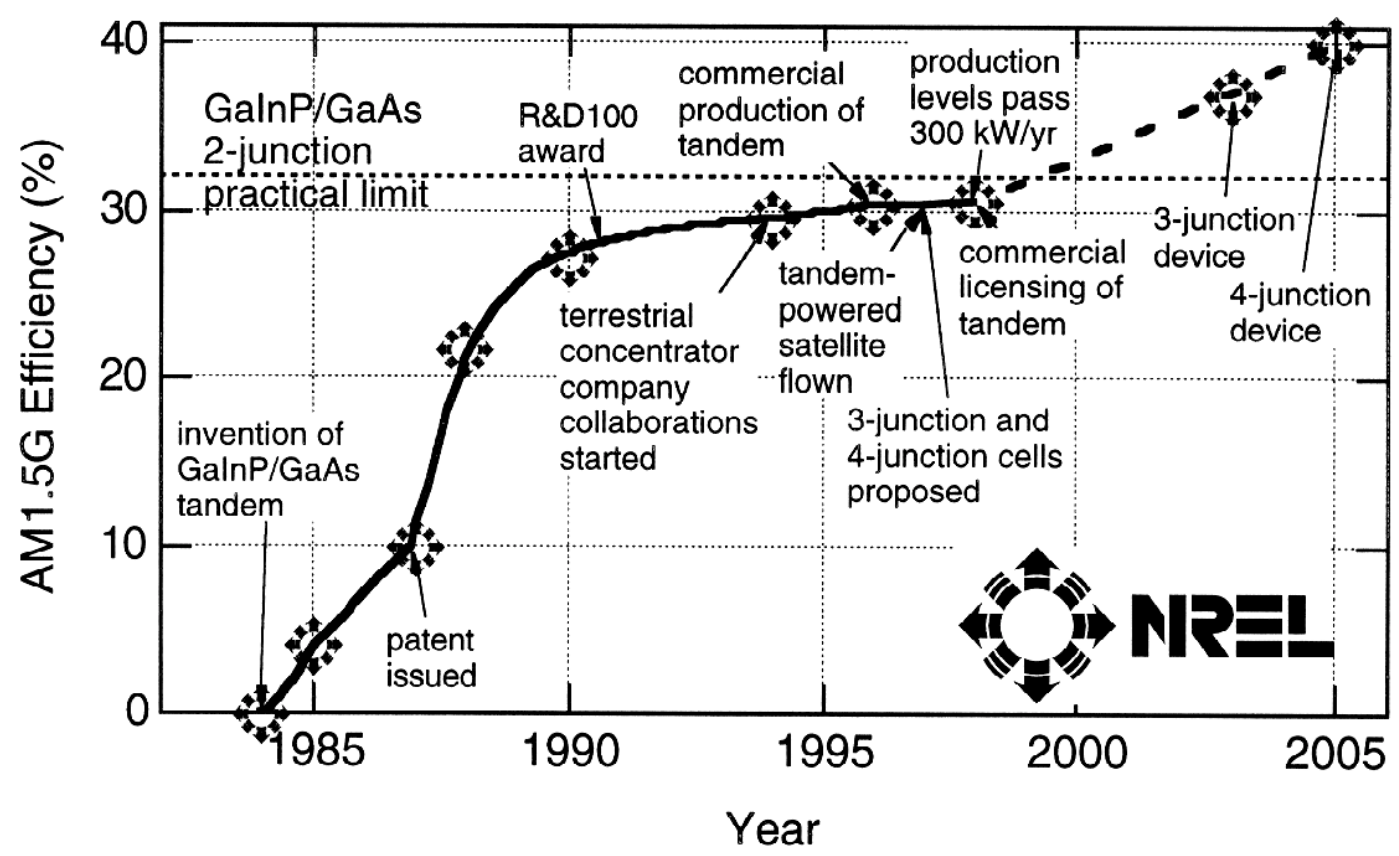

FIGURE 1. History (efficiency records, indicated by *) and future projections for highefficiency GaInP/GaAs cells.

\section{RECENT DEVELOPMENTS}

\section{Recent Developments in Manufacturing of GaInP/GaAs Cells}

With the help of the ManTech Program sponsored by the Air Force and NASA, the efficiencies and production volumes of $\mathrm{GaInP} / \mathrm{GaAs}$ cascade cells grown on $\mathrm{Ge}$ substrates have continued to climb (13-14). The addition of an active Ge junction, formed during the growth, pushed the best-cell AM0 efficiencies to $25.76 \%$ and $24.7 \%$ at Spectrolab and TECSTAR, respectively (13). The first commercial satellite with GaInP/GaAs cells was built by Spectrolab/Hughes and launched in August 1997 (15).

Over the last few years, production of III-V cells for use in space has increased dramatically (see Fig. 2). The current production capacity of III-V cells at TECSTAR is $350 \mathrm{~kW} / \mathrm{yr}$. Although most of TECSTAR's III-V production is single-junction cells, by the end of 1999 TECSTAR expects to convert all of its III-V production to cascade cells and increase production capacity to $520 \mathrm{~kW} / \mathrm{yr}$. Spectrolab is manufacturing the multijunction cells at a rate of $325 \mathrm{~kW} / \mathrm{yr}$, with $210 \mathrm{~kW}$ already delivered (15). If the sale price is $\$ 300 / \mathrm{W}$, the total current production capacity of GaInP/GaAs cells is > $\$ 100$ million/year, with about $\$ 100$ million worth already delivered. This is especially impressive because production just began in 1996.

In the spring of this year, TECSTAR and NREL signed a licensing agreement giving TECSTAR non-exclusive rights to manufacture GaInP/GaAs space cells. Others have also expressed an interest in licensing the technology. 


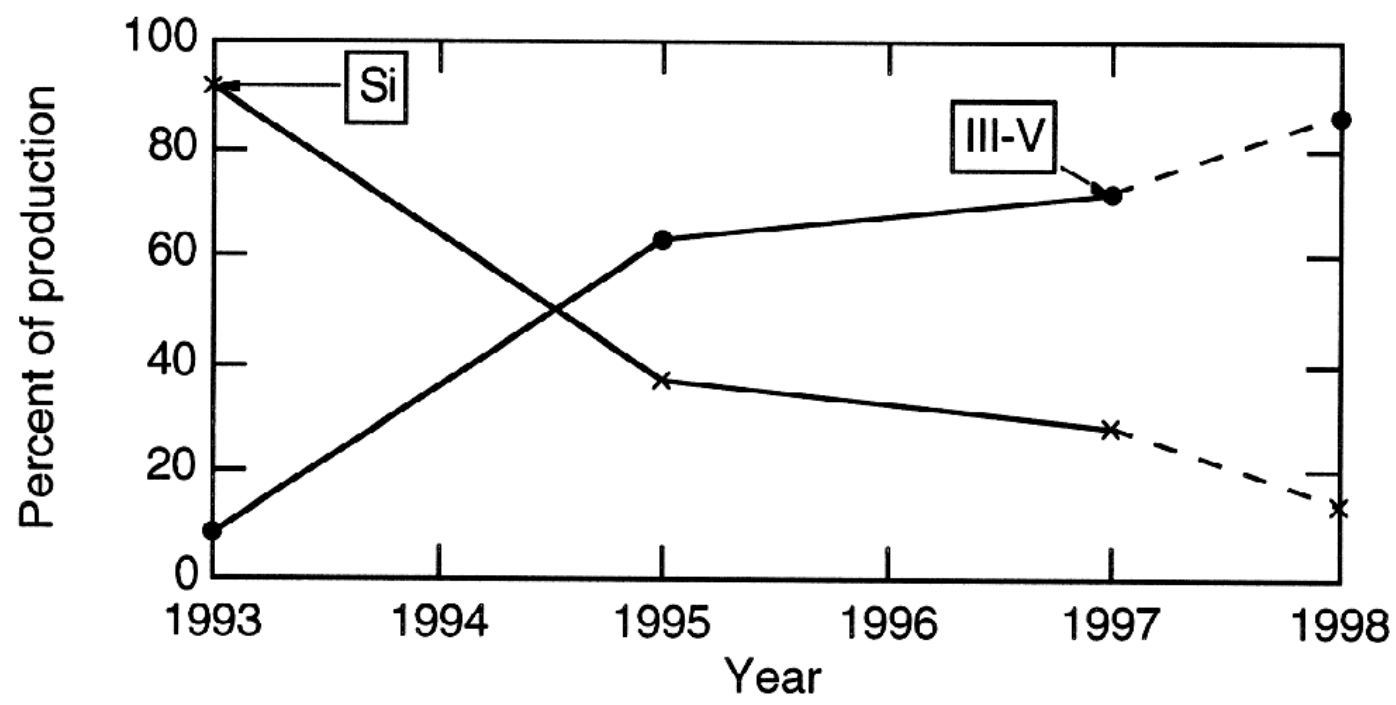

FIGURE 2. Distribution of TECSTAR production between Si and III-V, reflecting an increase in production of close to a factor of 10. Data courtesy of TECSTAR.

\section{III-V Space-Cell Production Makes Terrestrial Applications Attractive}

The current production capacity of about $700 \mathrm{~kW} / \mathrm{yr}$ of III-V cells for space would correspond to about $700 \mathrm{MWp} / \mathrm{yr}$ if the same cells were used at $1000 \mathrm{X}$ for terrestrial concentrator systems. This is roughly five times the total 1997 terrestrial PV sales. If the PV industry is to grow fast enough to supply a significant fraction of the world's energy 10-15 years from now, the industry may need to use concentrator systems.

The mass production of III-V devices has reduced the cost of III-V epitaxy. A recent EMCORE study showed that, at $90 \%$ yield and $10 \mu \mathrm{m} / \mathrm{h}$ growth rate, a 4 -in. Ge wafer with a GaInP/GaAs cell grown on it costs $\$ 210$ (16). If $90 \%$ of the 4 -in. wafer can be used to make $26 \% 1000 \mathrm{X}$ concentrator cells, the cell cost would be $21 \propto / \mathrm{Wp}$. (This assumes $90 \%$ optical efficiency, $850 \mathrm{~W} / \mathrm{m}^{2}$ irradiance, $10 \%$ area used for busbars, and that $25 \%$ of the cost is in processing.) Current prices for concentrator III-V cells can be expected to be at least 10 times this, largely because making the concentrator cells is a research project. These cells may be even more attractive for concentrator systems when the efficiencies are pushed higher with 3- and 4-junction concepts (17).

\section{Recent Developments in the Terrestrial Concentrator Industry}

BP Solar has almost completed a $0.5 \mathrm{MWp}$ system in Tenerife. This system uses reflective troughs with a concentration of $32 \mathrm{X}$ and BP Solar laser-groove buried grid $19 \%$-efficient silicon cells. The cost of electricity generated by the EUCLIDES concept is estimated at $12 \phi / \mathrm{kWh}$ compared with $22 \phi / \mathrm{kWh}$ for a flat-plate module (18).

In April 1998, Honda (19) unveiled a prototype 270X concentrator system using SunPower 26\%-efficient Si cells (see Fig. 3). Although Honda has not yet announced any plans for commercializing the concentrator system, the April report indicated that "Honda plans to launch the system for personal residential uses in the future." 


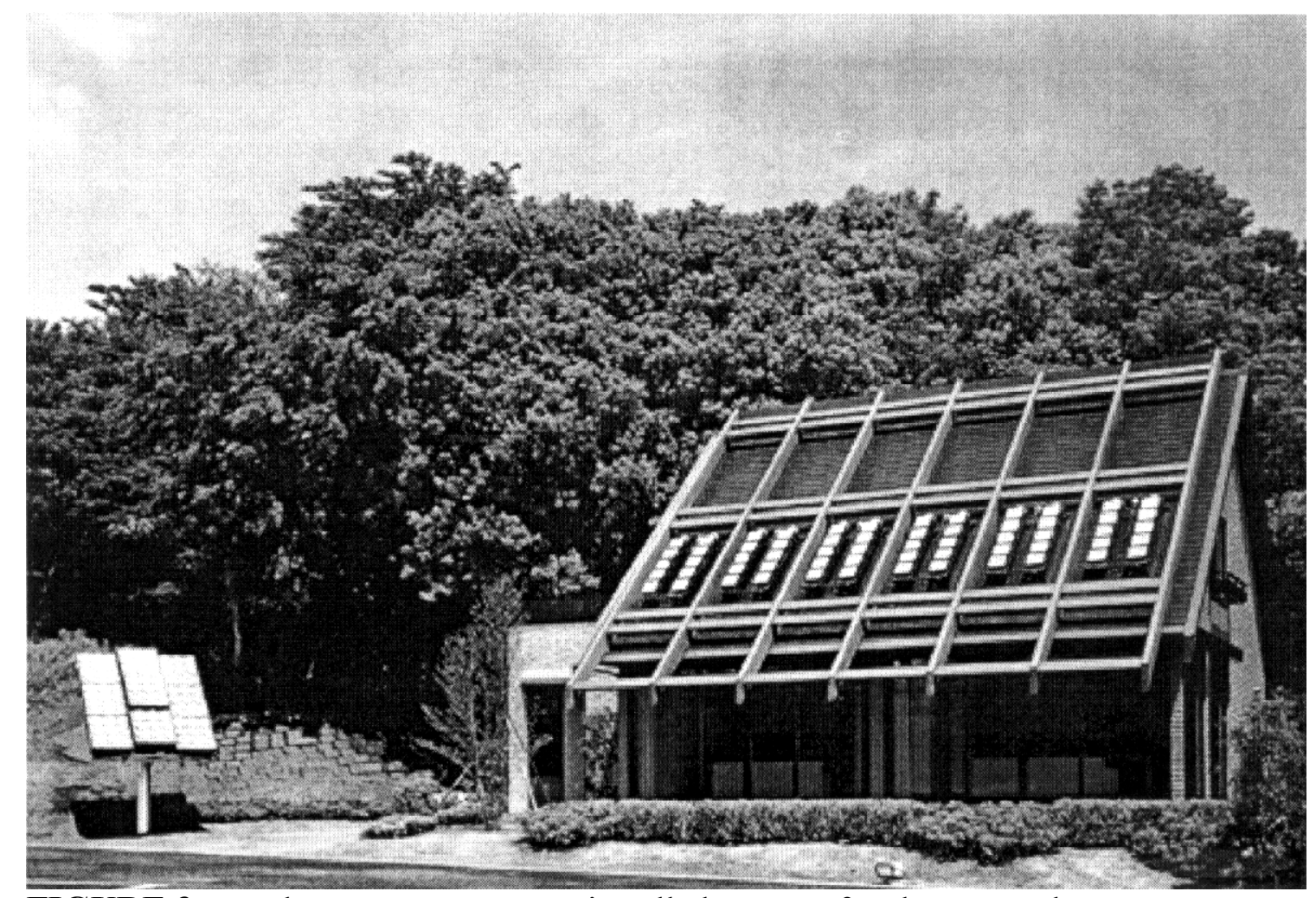

FIGURE 3. Honda prototype systems installed on top of and next to a house.

SunPower is also working with a number of other companies and expects total orders in 1999 of more than $1 \mathrm{MWp}$ of concentrator cells.

Amonix has installed a number of systems in the past year and is planning to install an additional $100 \mathrm{kWp}$ by the end of the first quarter of 1999 . These systems are being made on a $1 \mathrm{MWp} / \mathrm{yr}$ production line, reducing costs significantly.

SAIC is considering use of PV concentrator systems as an alternative to Stirling engines. High-efficiency silicon cells like those made at SunPower and Amonix could be used in the SAIC dish in the short term. High-voltage III-V multijunction cells are also being investigated for this sort of application (20). SAIC has estimated the capital cost of a $1000 \mathrm{MWp} / \mathrm{yr}$ dish/PV plant at $\$ 7$ million (\$5 million for the dish factory and $\$ 2$ million for the solar-cell plant), compared with an estimated $\$ 125$ million for a 1000 $\mathrm{MWp} / \mathrm{yr}$ crystalline-silicon production facility (21).

In Europe, the JOULE program has funded a number of projects in addition to EUCLIDES. At the University of Reading, ninety concentrator concepts using 40X or less were compared (22), and the best four were fabricated and tested $(23,24)$. A study by the University of Ulster and BP Solar evaluated a static, low-concentration design appropriate for building integration and concluded that $95 \%$ of the electrical output of a flat-plate system could be obtained with only $40 \%$ of the silicon (25). Static, lowconcentration systems have been shown elsewhere to be cost effective (26). Carefully designed, small-volume, non-imaging optics can achieve 200X, with an acceptance angle as large as $4.7^{\circ}$ and an average thickness-to-diameter ratio of only 0.48 (27). 
As the prospects for increased sales of terrestrial concentrator systems increase, both the concentrator and cell-manufacturing companies have expressed an interest in using multijunction III-V cells in terrestrial concentrator systems. In the past year, three proposals by private companies were submitted to various funding agencies requesting funding to develop III-V cells for terrestrial concentrator applications.

A common perception today is that the PV market will be dominated by buildingintegrated applications and that concentrator PV cannot compete for these markets. However, concentrator systems can be building integrated, as discussed above. Although many customers may choose a product without moving parts, creatively designed concentrator systems will be able to capture a share of the building-integrated PV market.

\section{Standards Development Provides Foundation for Industry}

In the past year, significant progress has been made toward developing standards for concentrator systems. NREL has coordinated the writing of IEEE Recommended Practice for the Qualification of Photovoltaic Concentrator Modules (28). The first modules will start through this test sequence in late 1998. The International Electrotechnical Commission will sponsor the development of a similar international standard (29). Sandia National Labs is coordinating an effort to write a test procedure for sun trackers (for both flat-plate and concentrator modules) (30). Many failures of concentrator modules have been linked to tracker problems (31), implying that this test procedure may be key toward improving concentrator-module performance.

In general, healthy growth of any industry requires carefully designed standards. Today's concentrator systems, strictly speaking, should all be viewed as prototypes. Because the qualification test procedure is not yet completed, no concentrator system has yet been qualified. Some concentrator modules were tested at Sandia, but the tests were not complete. In the days before an adequate qualification test was designed, flatplate modules also suffered failures. The failure rate dropped significantly for modules that passed the carefully designed qualification test. Similar improvements in concentrator module reliability can be expected when fielded systems have all passed an adequate qualification test.

\section{SUMMARY}

NREL's GaInP/GaAs cells have been enthusiastically accepted by the space PV industry because of their high efficiency, low temperature coefficient, and good radiation resistance, and are now being manufactured at $325 \mathrm{~kW} / \mathrm{yr}$ by Spectrolab. TECSTAR has a III-V cell production capacity of $350 \mathrm{~kW} / \mathrm{yr}$ and anticipates using all of that for $\mathrm{GaInP} / \mathrm{GaAs}$ cells by the end of 1999. This large manufacturing base has allowed the manufacturing costs to drop, to about $21 \phi / \mathrm{Wp}$ for $1000 \mathrm{X}$ concentrator cells. Costs are continuing to drop, and efficiencies may improve dramatically with new 3- or 4-junction concepts. Concentrator arrays using III-V cells are scheduled to fly on upcoming NASA missions (see Appendix). The advances of concentrators for space applications are paralleled by advances of the terrestrial concentrator industry. BP Solar is bringing a $0.5 \mathrm{MWp}$ system on line this fall, and Honda has unveiled a prototype of a concentrator system that can be roof-mounted. The development of qualification 
standards for concentrator systems is progressing well and is expected to help the industry in fielding reliable products. The sum of these recent developments, perhaps insignificant when isolated, point to a resurgence of interest in terrestrial PV concentrators as a strong option to become a significant future-generation PV technology.

\section{APPENDIX}

\section{Recent Developments of PV Concentrators in Space}

One of the current trends in space PV (32) is the use of concentrators. III-V cells are an obvious choice for concentrator systems because of their high efficiency, high voltage (low current), and low temperature coefficients. The potential advantages of concentrator arrays in space include improved radiation resistance, lower cost, higher efficiency, and a reduced capital investment for expansion of production capacity. Although there has been reluctance to use concentrator arrays in space because of their need to be accurately pointed at the sun, space concentrator technology is being pushed very hard by a number of organizations.

Popular Science recently featured NASA's Deep Space 1 (DS1) mission on its cover (33). DS1 is scheduled to launch in October 1998 and will not only fly past an asteroid and a comet, but will also be testing a dozen new cutting-edge technologies. The solar concentrator arrays are one of the new technologies, and, because they produce $50 \%$ more power per area than conventional arrays, they enable NASA to include another new, energy-hungry technology: ion propulsion. The development of these concentrator arrays was sponsored by the Ballistic Missile Defense Organization. Able Engineering assembled the arrays using TECSTAR-manufactured GaInP/GaAs cells and linear-focus lenses designed by ENTECH, Inc. $(34,35)$.

Concentrator solar arrays will be used to provide a portion of the electrical power for NASA's Wide Field Infrared Explorer mission and the Air Force's MightySat mission (36). In February, Spire Corporation completed a prototype panel using Spire's highefficiency GaAs space solar cells in lightweight concentrator array panels built by Composite Optics, Inc. Lightweight mirrors focus sunlight onto the cells, thus reducing the cost of the array. The need to maintain high pointing accuracy toward the sun is minimized by using a concentration ratio of less than three.

The National Reconnaissance Office has funded the development of graded-index solar concentrators. This work, done by the United Innovations Division of DR Technologies, Inc., uses both a reflector and a graded-index lens to focus the light to $50 \mathrm{X}$ on $\mathrm{GaInP} / \mathrm{GaAs}$ cells (37).

\section{ACKNOWLEDGMENTS}

We would like to thank the many people in industry who have worked with us over the years and shared information for this paper. We also thank B. McConnell for helpful comments. This work was completed under U.S. Department of Energy Contract No. DE-AC36-83CH10093. 


\section{REFERENCES}

1. Patent \# 4,667,059, 1987.

2. Olson, J. M., et al., "GaInP 2 /GaAs: A current- and lattice-matched tandem cell with a high theoretical efficiency," in Proceedings of the 18th IEEE Photovoltaic Specialists Conference, 1985, 552-555.

3. Olson, J. M., et al., "GaInP $2 / \mathrm{GaAs}$ monolithic tandem solar cells," in Proceedings of the 19th IEEE Photovoltaic Specialists Conference, 1987, 285.

4. Olson, J. M., et al., Proceedings of the 18th IEEE Photovoltaic Specialists Conference, 1988, 777.

5. Olson, J. M., et al., Proceedings of the 21st IEEE Photovoltaic Specialists Conference, 1990, 24.

6. Bertness, K. A., et al., Appl. Phys. Lett. 65, 989-991 (1994).

7. Friedman, D. J., et al., Progress in Photovoltaics: Research and Applications 3, 47-50 (1995).

8. Sharps, P. R., et al., Proc. of the First World Conference on PV Energy Conversion, 1994, 1725-1728.

9. Takamoto, T., et al., Proc. of the 1st World Conference on PV Energy Conversion, 1994, 1729-1732.

10. Chiang, P. K., et al., Proc. of the 1st World Conference on PV Energy Conversion, 1994, 2120-2123.

11. Yeh, Y. C. M., et al., Proceedings of the 25th Photovoltaic Specialists Conference, 1996, 187-190.

12. Chiang, P. K., et al., Proc. of the 25th IEEE Photovoltaic Specialists Conference, 1996, 183-186.

13. Keener, D. N., et al., Proc. of the 26th IEEE Photovoltaic Specialists Conference, 1997, 787-792.

14. Yeh, Y. C. M., et al., Proc. of the 26th IEEE Photovoltaic Specialists Conference, 1997, 827-830.

15. Cavicchi, B. T., et al., "250,000 Watts of $\mathrm{GaInP}_{2} / \mathrm{GaAs} / \mathrm{Ge}$ dual junction production," in Proceedings of the 2nd World Conference on PV Energy Conversion, 1998.

16. Kroll, W. J., et al., "MOCVD technology for advanced space solar cell production," in Proceedings of the 2nd World Conference on PV Energy Conversion, 1998.

17. Kurtz, S. R., et al., Proceedings of the 26th IEEE Photovoltaic Specialists Conference, 1997, 875.

18. Luque, A., et al., Progress in Photovoltaics: Research and Applications 5, 195-212 (1997).

19. Nikkan Kogyo, April 15, 1998.

20. Ward, J. S., et al., "Large-area, high-intensity PV arrays for systems using dish concentrating optics," in Proceedings of the 2nd World Conference on PV Energy Conversion, 1998.

21. Butler, B., presentation at Soltech, 1998.

22. Whitfield, G. R., et al., Proc. of the 14th European PV Solar Energy Conference, 1997, 336-339.

23. Weatherby, C. K. and Bentley, R. W., "Further development and field test results of two lowmaterial-cost parabolic-trough PVconcentrators," and Whitfield, G.R. et al., "Development and testing of optical concentrators for small PV systems, both in Proc. of the 2nd World Conference on PV Energy Conversion, 1998.

24. Hunt, A., "Design and manufacture of a point focus Fresnel-lens concentrator for a stand-alone PV system," and Alarte, E., et al., "Design, construction and measurement of a single-mirror two-stage photovoltaic concentrator" both in Proc. of the 2nd World Conference on PV Energy Conversion, 1998.

25. Eames, P. C., et al., Proceedings of the 2nd World Conference on PV Energy Conversion, 1998.

26. Swanson, R. M., in Proc. of the Future Generation Photovoltaic Technologies, 1997, 277-284.

27. Benitez, P. and Diaz, J. L., Proc. of the 2nd World Conference on PV Energy Conversion, 1998.

28. Contact R. McConnell at robert_mcconnell@nrel.gov for information on participating in this activity.

29. Contact J. Anderson at jerand@twave.net for information on participating in this activity.

30. Contact A. Maish at abmaish@sandia.gov for information on participating in this activity.

31. Lepley, T., et al., Proc. of the 26th IEEE Photovoltaic Specialists Conference, 1997, 1257-1260.

32. Bailey, S. G. and Flood, D. J., Progress in Photovoltaics: Research and Applications 6, 1-14 (1998).

33. DiChristina, M., Popular Science July, $42-47$ (1998).

34. Eskenazi, M. I., et al., Proc. of the 26th IEEE Photovoltaic Specialists Conference, 1997, 831-834.

35. Murphy, D. M. and Eskenazi, M. I., Proc. of the 26th IEEE PVSC, 1997, 861-864.

36. Spire, press release, Feb. 98.

37. Ortabasi, U., Report to National Reconnaissance Office under contract \#NRO-96-C-2003. 